\title{
PKM SANTRI PONDOK AL-HAMDANIYAH KECAMATAN BUDURAN DESA SIWALAN PANJI KABUPATEN SIDOARJO
}

\author{
Nurul Azizah', M Abror², Paramitha Amelia K ${ }^{3}$ \\ ${ }^{1}$ Universitas Muhammadiyah Sidoarjo \\ ${ }^{2}$ Universitas Muhammadiyah Sidoarjo \\ ${ }^{3}$ Universitas Muhammadiyah Sidoarjo
}

Nurul_az3zah@yahoo.com, email Penulis Kedua, paramitha_amelia@umsida.ac.id

\begin{abstract}
Abstrak
Pondok pesantren Al-Hamdaniyah belum optimal dalam menerapkan pola hidup bersih dan sehat, kamar mandi dan dapur dinilai kebersihannya kurang, mengakibatkan santri rentan gangguan nutrisi hingga terserang penyakit menular. Anehnya ketika santri sakit mitra beranggapan "berkah" yang bisa menjadikan ilmu bermanfaat, Tujuan PKM santri pondok pesantren Al-Hamdaniyah yakni pemberdayaan pola hidup bersih dan sehat agar terhindar dari gangguan nutrisi dan penyakit.

Solusinya yakni pelatihan pola hidup bersih dan sehat. serta memberikan pembelajaran dan pemberdayaan menanam hydroponik, dengan tujuan agar santri dapat hidup sehat dan terhindar dari penyakit, dan adanya lingkungan yang nyaman sehingga para santri dapat menuntut ilmu dengan baik.

Kegiatan PKM di mulai dengan seminar hydroponik, dan cara pemberdayaan tanaman hydroponik, dilanjutkan dengan penyerahan 2 paket peralatan tanaman hydroponik kepada mitra, Kegitan berikutnya seminar pendidikan pola hidup bersih dan sehat, meliputi kebersihan diri, pemenuhan kebutuhan gizi dan kebersihan lingkungan dilaksanakan pada 20 juli 2019, di lanjutkan dengan penyerahan beberapa peralatan kebersihan yang dapat dipergunakan mitra.

Hasil kegiatan PKM santri pondok pesantren Al-hamdaniyah dapat mempraktekkan kembali bagaimana cara penanaman dan pemeliharaan tanaman hydroponik sehingga nantinya dapat menikmati hasil tanaman hidroponik untuk dikonsumsi sehari-hari. Para santri juga dapat memahami pentingnya pola hidup bersih dan sehat, agar dapat menuntut ilmu dengan baik.
\end{abstract}

Kata kunci : santri alhamdaniyah, PHBS, hydroponik

\section{PENDAHULUAN}

\subsection{Analisis Situasi}

Uraian analisis situasi dari program kemitraan masyarakat santri pondok pesantren alhamdaniyah, desa siwalan panji kecamatan buduran sidoarjo jawa timur. Pondok pesantren alhamdaniyah merupakan salah satu pondok tertua di Indonesia Jumlah santri pondok alhamdaniyah saat ini saat ini skitar adalah 130 dengan luas pondok skitar 2000 meter persegi.

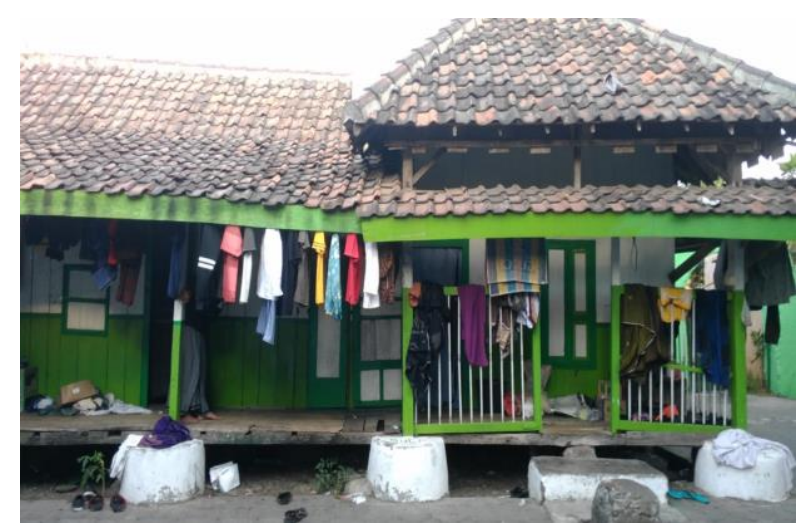


Pondok pesantren alhamdaniyah mempunyai kegiatan sekolah diniyah, pengajian kitab kuning (sorogan), yang bisa diikuti oleh setiap santri, namun selama ini belum ada yang kegiatan yang masuk di pondok meliputi pendidikan kesehatan atau kegiatan lain yang bertujuan untuk meningkatkan wawasan serta upaya perlakuan untuk hidup bersih dan sehat, serta pemeliharaan lingkunagn untuk membatu kehidupan santri pondok pesantren alhamdaniyah. Berdasarkan hasil observasi dilapangan menunjukkan bahwa pola hidup bersih kurang optimal diterapkan sehingga membutuhkan edukasi tentang pola hidup bersih dan sehat.

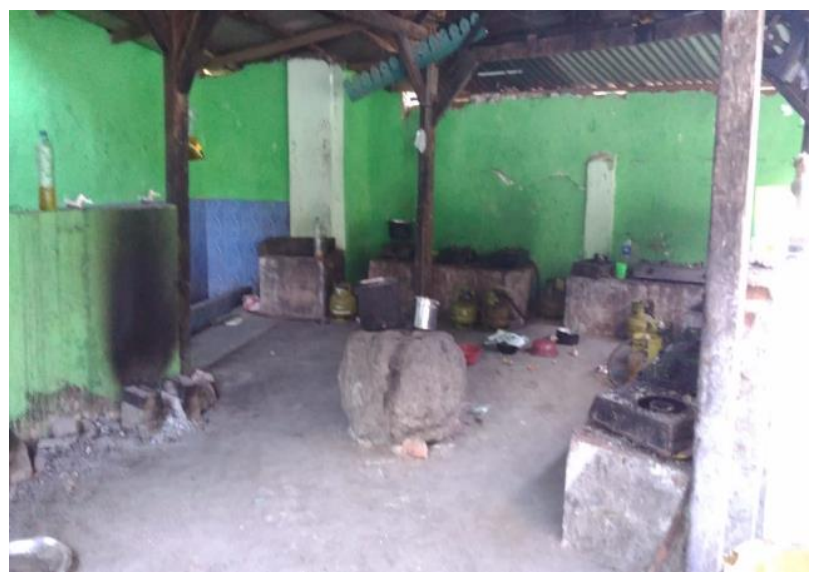

Santri pondok Al-Hamdaniyah sebagian besar dari madura, pasuruan dan probolinggo tujuan mondok untuk menimbah ilmu agama, sebagian besar santri berasal dari keluarga menengah kebwah sehingga dengan keterbatasan biaya para wali santri dapat mengirim anaknya untuk mondok di pesantren Al-Hamdaniyah, pondok Al-Hamdaniyah dikenal sangat murah bahkan jika santri tidak mampu membayar akan tetap diperkenankan tetap tinggal dan menimba ilmu di pondok. Fasilitas di pondok Al-Hamdanyah belum memenuhi standarisasi bagi kehidupan santri, misalnya untuk makan para santri masak dengan menggunakan dapur yang seadanya, dan menu seadanya pula tanpa memperdulikan perihal kebutuhan gizi dll.

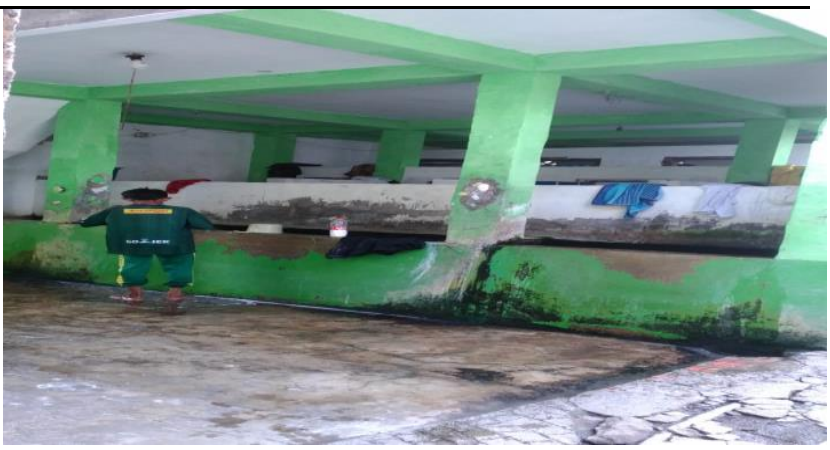

Upaya pemberdayaan hidup bersih dan sehat kepada mitra yakni santri pondok pesantren alhamdaniyah sangat penting, mengingat santri merupakan kategori remaja yang merupakn generasi penerus bangsa.

\subsection{Permasalahan Mitra}

1) Mitra yakni santri pondok pesantren alhamdaniyah masih belum mengetahui cara hidup sehat, mulai dari kebersihan kamar mandi, tempat baju yang telah digunakan, hingga dapur sebagai tempat masak masih jauh dari standart kebersihan, sehingga mengakibatkan santri rentan terserang penyakit gangguang nutrisi hingga penyakit menular seperti hepatitis dan penyakit kulit.

2) Mitra lingkungan pondok pesantren alhamdaniyah masih jauh dari kata bersih dan sehat, selain karena vasilitas dapur yang jauh dari standart kebersihan, disni para santri juga tidak dapat menciptakan lingkungan yang sehat. Sehingga tampak di area lingkunagan pondok tidak terlihat bersih dan sehat.

\subsection{Solusi Permasalahan}

Berdasarkan uraian dari analisis situasi dan permasalahan berikut solusi yang ditawarkan:

1) Agar mitra dapat melakukan pola kehidupan yang sehat sesuai dengan Keputusan Menteri Kesehatan tahun 2006 maka diperlukan sebuah pelatihan/workshop serta pemberdayaan pola hidup sehat dengan menciptakan lingkungan pondok yang bersih dan sehat, agar santri dapat hidup sehat dan terhindar dari penyakit sehingga dapat menyerap ilmu dengan baik.

2) agar mitra dapat menciptakan lingkungan yang bersih dan nyaman para santri akan di berikan bimbingan dan pemberdayaan menanam tanaman hydroponik, menerapkan cara pembuangan limbah dengan benar, pengadaan 
beberapa peralatan untuk menunjang vasilitas kebersihan mitradst.

\section{METODE}

Dimulai dengan kegiatan survei untuk melihat dan menganalisis situasi, kemudian melakukan pendekatan dan meminta persetujuan terhadap pimpinan untuk melakukan beberapa pelatihan dan pendampingan tentang Pola Hidup Bersih dan Sehat, hidroponik. Serta pemberdayaan kepada santri untuk menciptakan budaya dan lingkungan bersih dan sehat di pondok pesantren alhamdaniyah

Dalam pelaksanaan PKM santri pada pondok pesantren Al-Hamdaniyah ini kami melihat mempunyai kepentingan yang besar terhadap kesehatan mitra khususnya generasi muda, karena dalam hal ini para santri akan menjalani kehidupaanya bertahun2 di pondok, yang mana dengan adanya wawasan serta skill yang kami tawarkan harapannya dapat membuat para santri mendapatkan pengetahuan serta skill baru agar bisa diterapkan setiap hari bahkan budaya hidup bersih dan sehat tersebut dapat di wariskan pada generasi pondok pesantren al-hamdaniyah berikutnya.

\section{Sarana dan Prasarana}

Pondok pesantren al-hamdaniyah tentulah dibutuhkan sarana prasarana yang sesuai agar santri dapat menjalani kehiduan lebih baik, meliputi kebersihan lingkungan pondok pesantren yang meliputi, kamar santri, kamar mandi, dapur dan lingkungan skitar pondok seperti halaman

Dengan kegiatan pengabdian masyarakat ini tim akan berupaya membuat sarana prasana pondok menjadi lebih baik, bersih dan sehat, serta menanamkan pengetahuan dan pemberdayaan kepada para santri agar tahu dan dapat memberdayakan pola kebiasaan hidup bersihdan sehat dikemudian hari, hingga bisa diturunkan pada generasi berikutnya.

\section{Partisipasi Mitra}

Partisipasi mitra dalam kegiatan pondok pesantren al-hamdaniyah dengan penyediaan lahan untuk perbaikan fasilitas dan penanaman hydroponik dengan sumber daya santri dalam melaksanakan program hidroponik tersebut. Harapannya dengan kegiatan yang diadakan oleh tim pengusul mitra dapat berperan aktif dan mampu mengikuti serta menerapkan sesuai dengan pengetahuan pola hidup bersih dan sehat yaitu mengikuti pembelajaran dan pendampingan ini hingga selesai dan mitra dapat berkolaborasi dengan baik agar santri pondok pesanten alhamdaniyah untuk dapat hidup bersih dan sehat.

Kegiatan PKM ini diawali dengan pembelajaran kepada para santri, kemudian diikuti dengan pelatihan serta pendampingan agar mitra memberdayakan upaya mencipkatan lingkungan bersih dan sehat, dengan membenahi beberapa sarana dan prasarana yang dinilai kurang dari standart kebersihan dan kesehatan, dan memberdayakan penanaman tanaman hidroponik

\section{PELAKSANAAN \\ 1) Persiapan Pelatihan}

Koordinasi tim dilakukan dengan mitra yaitu pimpinan pondok pesantren Al-Hamdaniyah. Pada kegiatan ini tim pengabdian dan mitra membahas tentang kegiatan PKM yang akan dilaksanakan, tempat dan waktu pelaksanaan seminar dan pelatihan. Pada pertemuan ini ada beberapa hal yang disepakati, yaitu kegiatan sosialisasi kegiatan PKM, waktu dan tempat pelaksanaan seminar dan pelatihan, hydroponik dan perilaku hidup bersih dan sehat pondok pesantren dengan mengajak seluruh santriwan pondok pesasantren Al-Hamdaniyah.

Sebelum kegiatan seminar dan pelatihan hydrponik serta perilaku hidup bersih dan sehat terlebih dahulu tim pengusul mempersiapkan materi seminar, serta bahan-bahan untuk pelatihan pembuatan hydroponik dan serta seminar perilaku hidup bersih dan sehat pondok pesantren. Kegiatan seminar dan pelatihan dilaksanakan di aula pondok pesantren Al-Hamdaniyah bersama mitra yakni para santri, Rencana kegiatan implementasi tersebut mencakup:

a. Kegiatan seminat dan pelatihan hydroponik 
a) Mempersiapkan materi dalam bentuk powerpoint dan video yang ditampilkan saat pelaksanaan seminar bersama dengan mitra.

b) Mempersiapkan manual book (modul) cara pembuatan beserta perawatan tanaman hydroponik.

c) Pengadaan peralatan hydroponik

d) Praktek cara pembuatan dan pemeliharaan hydroponik

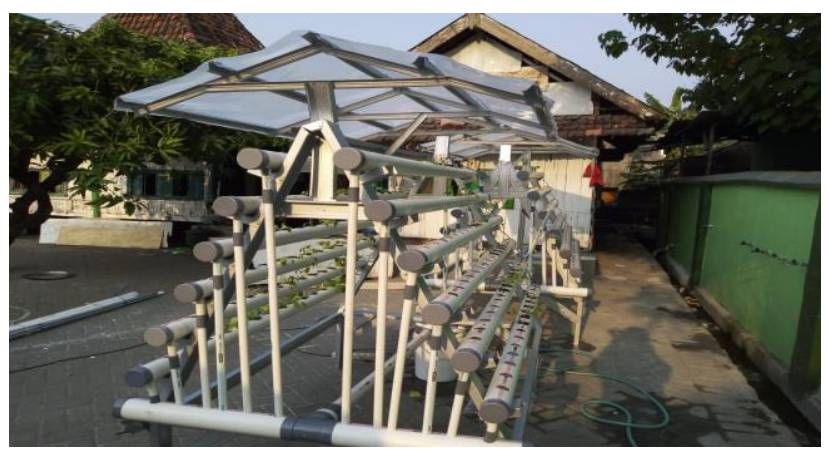

b. PHBS pondok pesantren

- Mempersiapkan materi dalam bentuk powerpoint dan video yang ditampilkan saat pelaksanaan seminar bersama dengan mitra.

- Pengadaan peralatan kebersihan, serta perbaikan beberapa sanitasi meliputi dapur dan kamar mandi,

- Praktek cara melakukan pola hidup bersih dan sehat

\section{2) Pelaksanaan Seminar}

\section{a. Pelaksanaan seminar hydroponik}

Kegiatan Seminar dan pelatihan tentang hydroponic kepada santri pondok pesantren AlHamdaniyah terlebih dahulu diperkenalkan dulu tentang jenis-jenis tanaman yang akan di tanam dalam hydroponik, cara penanaman dan cara pemeliharaan serta manfaat yang dapat diambil dari tanaman hydroponik Informasi semua ini bisa diketahui melalui seminar yang dilaksanakan oleh tim PKM dari UMSIDA (Universitas Muhammadiyah Sidoarjo).

Pelatihan pembuatan tanaman hydroponik meliputi:

a) Dimana para mitra terlebih dahulu diperkenalkan bahan-bahan apa saja yang mendukung untuk pembuatan tanaman hidroponik.

b) Menunjukkan peralatan-peralatan yang dipakai untuk proses pembuatan pembuatan tanaman hidroponik dan memiliki fungsi apa saja.

c) Menunjukkan ukuran atau takaran dalam pembuatan tanaman hidroponik.

d) Melatih bagaimana cara pembuatan tanaman hidroponik diikuti dengan penyerahan 2 set pelatahan hydroponik.

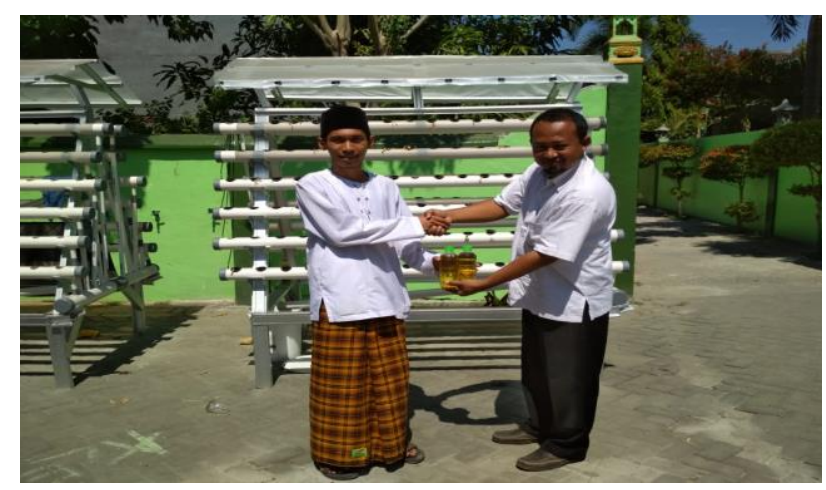

Seminar diadakan di aula pondok pesantren AlHamdaniyah kecamatan Buduran Kabupaten Sidoarjo. Seminar dan pelatihan hydroponic ini dilaksanakan hari sabtu, juni 2019, sedangkan di kegiatan pelaksanaan penenaman hydroponik dilaksanakan pada juni 2019 sesuai dengan peralatan yang ada.

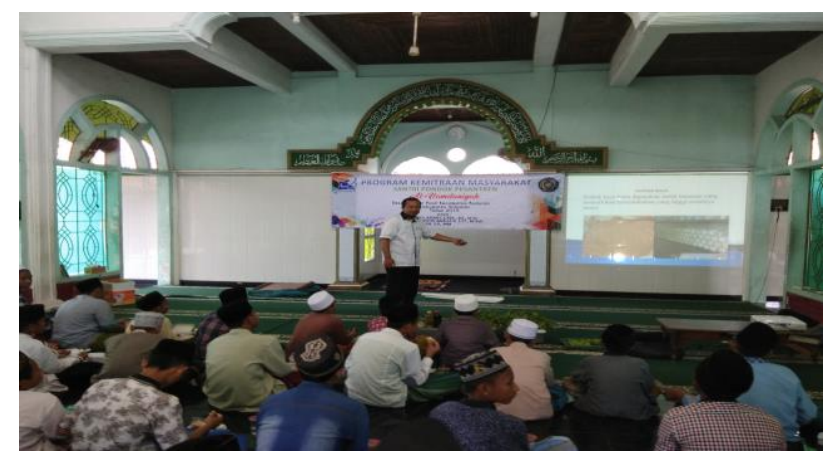

\section{b. Pelaksanaan seminar perlikau hidup bersih dan sehat pondok pesantren}

Kegiatan Seminar dan pelatihan tentang perilaku hidup bersih dan sehat pondok pesantren kepada santri pondok pesantren Al-Hamdaniyah terlebih dahulu diperkenalkan dulu tentang 
informasi perilaku hidup bersih dan sehat pondok pesantren, meliputi kebersihan diri, dan kebersihan lingkungan yakni pada lingkungan kamar, kamar mandi dan WC, tempat belajar (kelas), dan dapur.

Pelatihan pola hidup bersih dan sehat ini meliputi:

a) Dimana para mitra terlebih dahulu diperkenalkan tetang bagaimana cara menjalankan polah pola hidup bersih dan sehat.

b) Menunjukkan peralatan-peralatan yang dipakai untuk proses pola hidup bersih dan sehat dan memiliki fungsi apa saja dengan cara penggunaan yang benar.

c) Melatih bagaimana cara pelaksanaan pola hidup bersih dan sehat diikuti dengan penyerahan beberapa alat kebersihan, dan bahan-bahan untuk pelaksanaan kebersihan di lingkungan pondok.

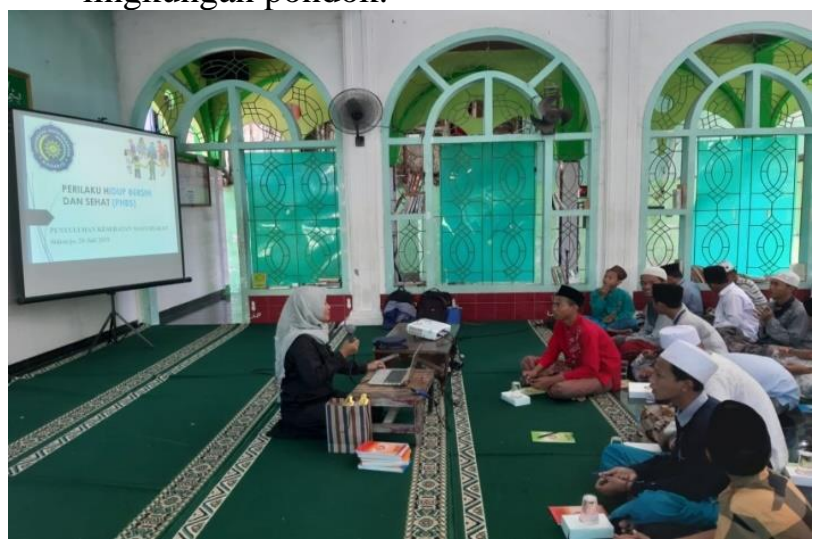

Seminar diadakan di aula pondok pesantren AlHamdaniyah kecamatan Buduran Kabupaten Sidoarjo. Seminar dan pelatihan perilaku hidup bersih dan sehat ini dilaksanakan hari sabtu, juli 2019, diikuti dengan penyerahan peralatan kebersihan.

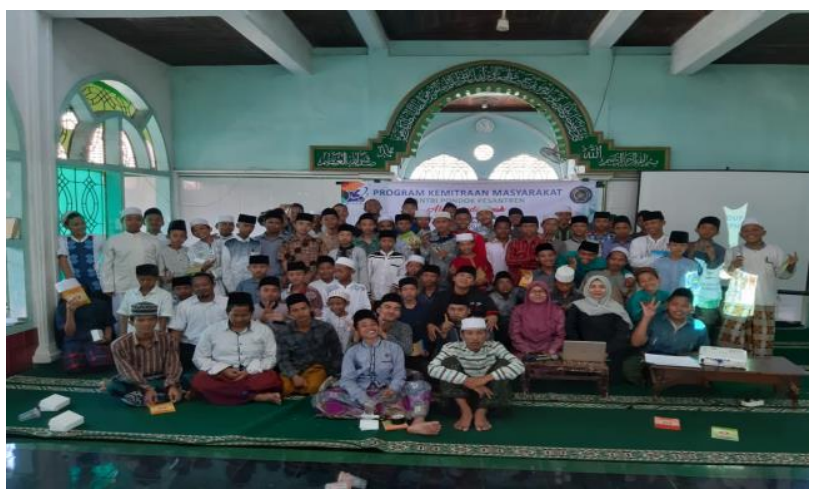

\section{KESIMPULAN}

Kegiatan PKM yang di lakukan di aula ponok pesantren Al-Hamdaniyah bersama dengan santri pondok pesantren Al-Hamdaniyah kecamatan Buduran kabupaten Sidoarjo.

1) Seminar dan pelatihan hydroponik diberikan dalam bentuk cerama, Tanya jawab serta aplikasi langsung tentang cara penanaman hydroponic, para santri dibimbing hingga benar-benar mengerti dan memahami serta dapat mempraktekkan kembali. Hasil menunjukkan para santri sangat antusias untuk mengikuti seminar dan pelatihan hydroponik ini, dengan di hadiri oleh seluruh para santri, serta kesanggupan para santri untuk melanjutka budi daya tanaman hydroponik.

2) Kegiatan selanjutnya yakni Seminar dan pelatihan tentang pola hidup bersih dan sehat yang diberikan dalam bentuk cerama, Tanya jawab serta aplikasi langsung tentang cara pola hidup bersih dan sehat, para santri dibimbing hingga benar-benar mengerti dan memahami serta dapat mempraktekkan kembali. Hasil menunjukkan para santri sangat antusias untuk mengikuti seminar dan pelatihan pola hidup bersih dan sehat pada pondok pesantren ini, dengan di hadiri oleh seluruh para santri, serta kesanggupan para santri untuk melaksanakan pola hidup bersih dan sehat, mengingat beberapa bahaya terjadinya penyakit menular dan penyakit yang membahayakan. Sehingga membuat para santri menyadari dan mau melaksanakan pola hidup bersih dan sehat. 


\section{UCAPAN TERIMAKASIH}

1. Kepada Pondok pesantren Al-Hamdaniyah yang telah bersedia berkontribusi atas kegiatan ini

2. Kepada universitas Muhammadiyah Sidoarjo atas bantuan semua pihak sehingga kegitan PKM ini dapat terlaksana dengan baik

\section{REFERENSI}

1. Gomes, Faustino C. 2003. Manajemen Sumber Daya Manusia.Yogyakarta : Andi Offset
2. Slamet, Soemirat J. 2009, Kesehatan Lingkungan. Yogyakarta: Gadjah Mada University Press

3. Wood, Jack, Joseph W, Rachid M, Zeffane, 2001. Organizational Behavior a Global Perspectives. Australia : John Willey \& Sons.

4. Rivai, Veithzal. 2005. Performance Appraisal. Jakarta: PT Raja Grafindo Persada 